CHAPTER XX

\title{
A calculation model for ergonomics cost-benefit analyses in early product development stages
}

\author{
Ann-Christine Falck, Mikael Rosenqvist \\ Department of Product and Production Development \\ Chalmers University of Technology \\ SE-41269, Göteborg, Sweden \\ annchrif@chalmers.se
}

\begin{abstract}
Increasing international competition between companies has put high focus on cost-cutting actions at all levels in companies and organizations. In product development there are many design requirements to meet and often tough project budgets to keep. Requirements that are considered not profitable will often be neglected, which often affects assembly ergonomics. The objective of this study is to demonstrate the relationship between ergonomics, assembly related quality errors and associated costs and develop a cost-beneficial assessment model. The results showed that ergonomics high risk issues had 5-8 times as many quality errors as low risk issues and the earlier risk issues were found the less were the action costs. A model for cost-benefit analyses was developed based on the obtained quality data.
\end{abstract}

Keywords: ergonomics, cost-benefit analyses, product development

\section{INTRODUCTION}

Corrective measures are often made late and reactively when problems have already occurred. Proactive ergonomics risk identification in early product development stages is still unusual although there is today much scientific evidence available that prove both the human and economic benefits (Dul and Neuman 
(2009). One of the main reasons may be a lack of knowledge about human and technology interaction and its impact on quality and productivity (Broberg, 1997; Skepper et al., 2000; Langaa Jensen, 2002, Sunwook et al., 2008). Skepper et al. (2000) argued that engineers and designers have poor knowledge of how to apply ergonomics principles. In product development departments there are many requirements for design engineers to meet and often tough project budgets to keep. This places high demands on very clear requirements and cost-beneficial solutions. Wulff et al. (2000) and Sunwook et al. (2008) claimed that requirements that are not easily understood or considered not profitable will be neglected, which often affects ergonomics. In addition, the time pressures in product design make designers reluctant to accept new requirements (Haslegrave and Holmes, 1994; Sunwook et al., 2008). Besides, cost-benefit analyses that demonstrate the profitability of ergonomics interventions are scarce. This is a difficult and complicated task since the straight-out and necessary data and related costs are not easily found in company records and in many cases missing altogether. Bevis and Slade (2003) found that few organizations make follow-ups for as long as necessary to be able to measure the long-term results. Nevertheless, it is urgent to be able to demonstrate the benefits of good ergonomics in economic terms. There are some good examples based on real world data such as by e.g. Hendrick (2003); Beevis and Slade (2003); Yeow and Nath Sen (2006), Goggins et al. (2008). Maudgalya et al. (2008) reviewed eighteen published cases studies with respect to productivity, quality, costs and safety. Regarding workplace safety initiatives, the studies showed an average increase of productivity of $66 \%, 44 \%$ in quality, $82 \%$ in in safety records and $71 \%$ in cost benefits. In a few reported cases it took only 8 months to obtain payback in terms of monetary investment. Hendrick (2008) presented 23 successful cases of ergonomic interventions in different companies in the U.S. He found that good ergonomics projects typically give a direct cost benefit of 1 to 2 , to 1 to 10 , with a typical payback period of 6-24 months. He calls attention to the fact that the language of business is money and accordingly ergonomic project proposals must be expressed in financial terms. Besides Hendrick (2003, 2008) Beevis and Slade (2003), Dul and Neumann (2009), Morse et al. (2009), strongly argue that ergonomists must learn to present ergonomics concerns in business terms.

When there are aggravating assembly conditions such as too high assembly forces, awkward working postures, concealed assembly or tricky assembly in general things are more likely to go wrong and need to be repaired and/or exchanged (Eklund, 1995; Falck et al., 2010). On paced assembly lines there is often too little time for immediate actions. Instead much corrective measures and exchange of parts have to be conducted afterwards in separate repair stations. This circumstance causes late deliveries and results in productivity losses because the work has to be remade. In addition to tasks with high physical demands, Eklund (1995) found that designs that were difficult to assemble caused even more quality deficiencies. Also psychologically demanding tasks contributed to quality deficiencies. Falck (2007) and Falck et al. (2010) made conclusions very similar to Eklund (1995).

Research by Eklund (1997, 1999), Falck (2007) and prolonged experience from the Swedish car industry (Saab Automobile and Volvo Cars) has shown that the ergonomic impact is caused by product design at $60-70 \%$. 30-40\% of the problems 
depend on production conditions in the factory such as work organization, work station design, operator behavior and skill etc. After major design and assembly concepts are determined the possibility to influence these decisions is limited. In the car industry this usually happens several years before production start. Haslegrave and Holmes (1994) and Falck et al. (2010) argued that ergonomics input should be made from the very start of a project near the concept stage to avoid later problems that can be very costly.

\section{OBJECTIVES}

The objective of this study is to demonstrate the relationship between ergonomics, assembly quality and related costs for correction of assembly errors. A further objective is to develop a calculation model for ergonomics cost-beneficial assessments and comparison of different manual assembly solutions.

\section{METHODS}

57 manual assembly tasks in a Swedish automotive company were chosen for analysis. 20 assembly tasks were chosen that were assessed to imply high ergonomics risk with harmful impact; 19 tasks were chosen at moderate ergonomics risk level and another 18 tasks at low ergonomics risk level with minor or no harmful impact on operators. The selection of assembly tasks was made in cooperation with ergonomics specialist and responsible engineers in manufacturing engineering. However, some of the assembly tasks were part of the same assembly description, which resulted in 50 assembly tasks (PII) to study. These represented various ergonomics load levels and assembly difficulty as assessed by the ergonomics specialist and manufacturing engineers. The selected tasks were studied during a period of twelve weeks. Quality deficiencies such as failure rate, scrap and costs for correction of assembly related errors were retrospectively collected and analyzed including warranty and repair costs at dealers. The study used data stored in the logging quality databases in the company. However, of the 50 assembly tasks 47 remained because three had to be excluded due to circumstances such as equipment failures and supplier related problems.

\subsection{Tracking quality errors and costs}

All errors, scrap and related costs of four car variants were tracked. The data was collected from eight different quality tracking systems partly through assistance from responsible quality engineers and team leaders in production.

- Quality errors and action time online and offline in the plant.

Because the the study was done retrospectively the established error codes of each assembly task had to be searched out in two quality monitoring systems (Atacq). Each assembly had between 8 and 74 five or six-digit specific error codes, which had to be looked up. These codes then manually had to be transferred to another quality tracking system (Business Object) that stored quality data for longer periods 
of time. After input of current codes and necessary main criteria wanted such as car variants, error codes, causing team, repair station, and investigation period, the system presented the numbers and types of errors that had occurred during the chosen period of investigation. The error data was divided into errors that occurred and were taken care of online and errors that had to be corrected offline. This division was a condition for accurate calculation of action times, which differed between action time online that was very short due to high time pressure and action time offline that was much longer due to less time pressure. Reported errors and required action times were converted into an hourly rate that was obtained from the economy department in the factory.

\section{- Scrap and exchange of parts}

The numbers and costs for parts and components that were replaced (scrapped) due to assembly related problems were obtained from the material coordinators in the plant.

\section{- Audit and blocked cars}

Each week 27 cars were randomly picked (audit= weekly sampling ) from the total amount of built cars for careful analysis of any errors that might have been missed earlier. In the cases where a series of cars were faulty these were taken aside (blocked cars) and carefully examined and fixed before leaving the assembly plant. Quality deviations (errors) found at audit and in blocked car series were included in this study.

- Warranty and repair costs at dealers

Problems and errors that are found on the market are continuously reported and logged. Quality teams (VRT and PFU) follow-up concept related assembly issues and product related quality issues of all ready cars that have left the factory. The numbers and costs for errors, which are usually found before the customers receive their cars, are logged. Errors and action costs associated with the selected assembly tasks were obtained from responsible quality engineers and included in the study.

\section{- Serious quality deficiencies found in the market}

Problems that might cause serious accidents or require frequent repair office visits are taken care of by a special team (FARG). This team deals with problems that can result in recalls of sold cars or in requests to bring cars to repair shops as soon as possible. Usually these problems cost a lot of money for the company. The numbers and action costs related to this study were investigated through assistance from responsible quality engineers.

\subsection{Action time and cost-analysis for quality errors in production}

The 47 assembly tasks for analysis represented 24 interior and 23 exterior assembly tasks of four car variants. The frequency, number of quality errors and costs were obtained from the different quality tracking databases described in section 3.1 .

- Calculation of action times online and offline in the plant

The action times for errors online were on average 2.2 minutes (Falck, 2010). Action times offline were obtained by the teams responsible for correction of errors offline. These average action times were then used for calculation of the costs for 
corrective measures offline. A labor cost of 360 SEK/hour* was used, which was obtained from the economy department in the plant.

*(Exchange rate at midtime of the study, February, 2019: 1SEK $=0,10$ EUR or 1 $\mathrm{EUR}=9,89 \mathrm{SEK}$ and $1 \mathrm{SEK}=0,14 \mathrm{USD}$ or $1 \mathrm{USD}=7,26 \mathrm{SEK})$.

\section{$4 \quad$ RESULTS}

- Failure rate, action times and action costs

The study covered four different car variants that were built on paced assembly lines during a period of twelve weeks. 47 tasks of 47061 cars were analyzed regarding failure rate associated with manual assembly (Table 1). All errors found in company records and quality monitoring systems were included. For 38 of the assembly tasks it was also possible to calculate both the failure rate and costs for corrective measures related to 26219 of the cars (Table 5,6). In Table 1 the results show that the increased risk of failure rate was 7.8 times for the high load level tasks and 5.3 times for the the moderate load level tasks compared to the low load level tasks. The increased risk of failure rate per PII (assembly task) was 6.3 times for the high load level tasks and 3.8 times for the moderate load level tasks compared to the low load level tasks. Altogether, the errors related to high and medium load level issues composed $92.9 \%$ of all analyzed tasks.

Table 1. Failure rate of all assembly tasks related to ergonomics load levels.

\begin{tabular}{llllll}
\hline Load level & $\begin{array}{l}\text { No. PII } \\
\text { (Assembly } \\
\text { Task) }\end{array}$ & $\begin{array}{l}\text { Total } \\
\text { failure } \\
\text { rate }\end{array}$ & $\begin{array}{l}\text { Quality errors } \\
- \text { percentage } \\
\text { share }\end{array}$ & Error/PII & $\begin{array}{l}\text { Increased } \\
\text { risk of } \\
\text { failure } \\
\text { rate }\end{array}$ \\
\hline High & 16 & 5045 & $55,1 \%$ & 315 & 7,8 times \\
Moderate & 18 & 3455 & $37,8 \%$ & 192 & 5,3 times \\
Low & 13 & 650 & $7,1 \%$ & 50 & 1 \\
All & 47 & 9150 & $100 \%$ & 195 & \\
\hline
\end{tabular}

For 38 of the 47 tasks the failure rate could be divided into errors that were corrected online and errors that must be corrected offline due to more time consuming repair. The average assembly time for the 38 tasks was 1789 TMU:s (just about 64 seconds per car since $1 \mathrm{TMU}=1 / 28^{\text {th }}$ of a second). During twelve weeks this includes 1782420058 TMU:s (about 1060964 minutes or roughly 17683 assembly hours). Table 2 . shows the distribution of errors that were taken care of online and offline. 3570 errors $(67.1 \%)$ were handled online, which is about twice as many as the 1747 errors (32.9\%), which were taken care of offline. Scrapped parts and components were altogether 433 pieces and included in the total failure rate of 5750 errors in the assembly plant. 18 errors that were found by from Audit were included in the numbers of errors offline since these were taken care of there. No errors in blocked car series were found in this study. The failure rate and action costs reported by the VRT/PFU and FARG teams are shown in Table 3. Here, the numbers of errors of the moderate load level tasks by far exceed the numbers of the 
high load level assembly tasks, 23 errors compared to 284. Besides, they are 1.7 times as expensive. The low load tasks only caused two errors but at a repair cost of

Table 2. Load level task errors divided into online and offline measures.

\begin{tabular}{lllllllll}
\hline Online & \multicolumn{7}{c}{ Offline } & \multicolumn{3}{c}{ All } & & \\
\hline $\begin{array}{l}\text { Load } \\
\text { level }\end{array}$ & $\begin{array}{l}\text { Errors } \\
\text { online }\end{array}$ & $\begin{array}{l}\text { Error } \\
\text { /PII }\end{array}$ & $\begin{array}{l}\text { Error } \\
\text { off } \\
\text { line }\end{array}$ & $\begin{array}{l}\text { Error } \\
\text { /PII }\end{array}$ & $\begin{array}{l}\text { Total } \\
\text { no. of } \\
\text { errors }\end{array}$ & $\begin{array}{l}\text { Scra } \\
\text { pped } \\
\text { items }\end{array}$ & $\begin{array}{l}\text { Total } \\
\text { no. of } \\
\text { errors }\end{array}$ & $\begin{array}{l}\% \text { of all } \\
\text { errors }\end{array}$ \\
\hline $\begin{array}{l}\text { High } \\
(n=14)\end{array}$ & 1942 & 138,7 & 1195 & 85,4 & 3137 & 176 & 3313 & 57,6 \\
$\begin{array}{l}\text { Moder } \\
\text { ate } \\
(n=14)\end{array}$ & 1106 & 79 & 497 & 35,5 & 1603 & 204 & 1807 & 31,4 \\
$\begin{array}{l}\text { Low } \\
(n=10)\end{array}$ & 522 & 52,2 & 55 & 5,5 & 577 & 53 & 630 & 11 \\
$\begin{array}{l}\text { All } \\
(n=38)\end{array}$ & 3570 & 93,9 & 1747 & 46 & 5317 & 433 & 5750 & 100 \\
\hline
\end{tabular}

799.76 SEK each. The high amount of errors and and costs of the moderate load level tasks were mainly caused by one single task, the front side window assembly that alone resulted in 267 errors and 219423 SEK in repair costs (does not show in Table 3).

For calculation of action times online (Table 4) a standard time of 2.2 minutes was obtained from previous analyses in the plant (Falck, 2010). However, the action times offline are not logged in any system and the only way to know was to ask very experienced operators to estimate the average action time for each type of error that was taken care of. The action times varied considerably and were between 2180 minutes per error depending on type of error and degree of severity. These average action times were used for calculation of the costs for corrective measures offline (Table 5, 6). For that purpose a labor cost of 360 SEK/hour was used, which was obtained from the economy department in the plant.

Table 3. Failure rate and action costs in the market.

\begin{tabular}{ccccccc}
\hline $\begin{array}{c}\text { Load level } \\
\text { (tasks) }\end{array}$ & $\begin{array}{c}\text { Errors } \\
\text { reported } \\
\text { by VRT } \\
\text { and PFU }\end{array}$ & $\begin{array}{c}\text { Errors } \\
\text { reported } \\
\text { by } \\
\text { FARG }\end{array}$ & $\begin{array}{c}\text { Total } \\
\text { failure } \\
\text { rate }\end{array}$ & $\begin{array}{c}\text { Action } \\
\text { cost/ } \\
\text { error, } \\
\text { SEK }\end{array}$ & $\begin{array}{c}\text { Action } \\
\text { cost/ } \\
\text { task } \\
\text { SEK }\end{array}$ & $\begin{array}{c}\text { Total } \\
\text { action } \\
\text { cost, } \\
\text { SEK }\end{array}$ \\
\hline $\begin{array}{c}\text { High }(n=14) \\
\text { Moderate } \\
(n=14)\end{array}$ & 23 & 0 & 23 & 466,17 & 765,86 & 10722 \\
Low $(n=10)$ & 284 & 0 & 284 & 799,76 & 16223,64 & 227131 \\
All $(n=38)$ & 309 & 0 & 2 & 1220 & 224 & 2440 \\
\hline
\end{tabular}

The overall offline action times were 20. 24 minutes/error, i.e. 9.2 times longer compared to the action times/error online of 2.2 minutes (Table 4). The low load level tasks specifically had a much higher average action time offline of 53.22 
minutes/error. This was caused by two assembly tasks that required very timeconsuming disassembly and replacement of parts. However, the average action times/error on- and offline for all load levels did not differ much. The total action costs of the 38 assembly tasks are shown in Table 5. In the plant the high load level tasks corresponded to $48.7 \%$ of the costs, the moderate load level tasks to $41.1 \%$ and the low load level tasks to $10.2 \%$. However, in the market the moderate load level tasks accounted for $94.5 \%$ of the total repair cost mainly due to one of 14 tasks (the front side window), which alone caused 267 of 284 errors found in the market (see Table 3). These errors cost 821.80 SEK each to repair compared to repair in the plant which amounted to 78.08 SEK each. This means that the repair cost in the market was 10.5 times as expensive as repair in the plant. Table 6 shows the increased costs per error the later actions are taken. The lowest actions costs are online whereas issues taken care of offline are 10.53 times more costly to fix. Errors

Table 4. Failure rate and action times (minutes) in the plant.

\begin{tabular}{llllllll}
\hline Online & & \multicolumn{3}{c}{ Offline } & & All \\
\hline $\begin{array}{l}\text { Load } \\
\text { level }\end{array}$ & $\begin{array}{l}\text { Errors } \\
\text { on } \\
\text { line }\end{array}$ & $\begin{array}{l}\text { Mean } \\
\text { action } \\
\text { time/ } \\
\text { error }\end{array}$ & $\begin{array}{l}\text { Total } \\
\text { action } \\
\text { time }\end{array}$ & $\begin{array}{l}\text { Errors } \\
\text { off } \\
\text { line }\end{array}$ & $\begin{array}{l}\text { Total } \\
\text { action } \\
\text { time }\end{array}$ & $\begin{array}{l}\text { Mean } \\
\text { action } \\
\text { time/ } \\
\text { error }\end{array}$ & $\begin{array}{l}\text { Mean } \\
\text { action } \\
\text { time/ } \\
\text { error }\end{array}$ \\
\hline $\begin{array}{l}\text { High } \\
(n=14)\end{array}$ & 1942 & 2,2 & 4272,4 & 1195 & 22728 & 19,02 & 8,607 \\
$\begin{array}{l}\text { Moderat } \\
\text { e }(n=14)\end{array}$ & 1106 & 2,2 & 2433,2 & 497 & 9637 & 19,39 & 7,529 \\
$\begin{array}{l}\text { Low } \\
(n=10)\end{array}$ & 522 & 2,2 & 1148,4 & 55 & 2997 & 53,22 & 7,184 \\
$\begin{array}{l}\text { All } \\
(n=38)\end{array}$ & 3570 & 2,2 & 7854 & 1747 & 35362 & 20,24 & 8,127 \\
\hline
\end{tabular}

fixed in the market are 12,2 times as costly as errors fixed at plant level. Consequently, further efforts should be made to find errors and fix them as soon as possible.

Table 5. Total action costs of 38 assembly tasks in the plant and in the market.

\begin{tabular}{lllllll}
\hline Load & $\begin{array}{l}\text { Action } \\
\text { costs in } \\
\text { the plant, } \\
\text { SEK }\end{array}$ & $\begin{array}{l}\text { Plant } \\
\%-a g e \\
\text { of } \\
\text { action } \\
\text { costs }\end{array}$ & $\begin{array}{l}\text { Action } \\
\text { costs in } \\
\text { the } \\
\text { market, } \\
\text { SEK }\end{array}$ & $\begin{array}{l}\text { Market } \\
\% \text {-age } \\
\text { of } \\
\text { action } \\
\text { costs }\end{array}$ & $\begin{array}{l}\text { Total } \\
\text { action } \\
\text { costs, } \\
\text { SEK }\end{array}$ & $\begin{array}{l}\text { o-age } \\
\text { of all } \\
\text { action } \\
\text { costs }\end{array}$ \\
\hline $\begin{array}{l}\text { High } \\
(n=14)\end{array}$ & 177993,93 & 48,7 & 10722 & 4,5 & 188715,93 & 31,1 \\
$\begin{array}{l}\text { Moderate } \\
(n=14)\end{array}$ & 150462,19 & 41,1 & 227131 & 94,5 & 377593,19 & 62,3 \\
$\begin{array}{l}\text { Low } \\
(n=10)\end{array}$ & 37420,82 & 10,2 & 2440 & 1,0 & 39860,82 & 6,6 \\
All $(n=38)$ & 365876,94 & 100 & 240293 & 100 & 606169,94 & 100 \\
\hline
\end{tabular}


Table 6. Cost comparisons between different levels of action.

\begin{tabular}{ccccc}
\hline $\begin{array}{c}\text { Action } \\
\text { level }\end{array}$ & $\begin{array}{c}\text { Total action } \\
\text { costs, SEK }\end{array}$ & $\begin{array}{c}\text { Failure } \\
\text { rate }\end{array}$ & $\begin{array}{c}\text { Cost/error, } \\
\text { SEK }\end{array}$ & Increased costs \\
\hline Online & 47113 & 3570 & 11,52 & 1 \\
Offline & 211968 & 1747 & 121,33 & $\begin{array}{c}10,53 \text { times } \\
\text { compared to online }\end{array}$ \\
\hline Total plant & 365877 & $5750^{*}$ & 63,63 & 1 \\
Market & 240293 & 309 & 777,65 & $\begin{array}{c}12,2 \text { times } \\
\text { compared to total plant }\end{array}$ \\
\hline All & 606170 & 6059 & 100,04 & \\
\hline * including scrapped items reported on plant level.
\end{tabular}

\subsection{A calculation model for cost-benefit analyses}

Based on the detailed quality data obtained in this study, a calculation model was developed. The purpose of the model is to support decision making when necessary in the development of assembly solutions. The model enables cost-benefit analyses and comparisons between different assembly solutions and tasks and considers a majority of all costs in the plant and in the market. In this study, for each assembly task the numbers of quality errors online and offline and their respective action times were known. The amount and costs of scrapped items, quality remarks in audit and blocked cars were available. The labor costs could be calculated. The action costs of quality errors on the market or at the customer were also obtained. The costs for lost brand image are very difficult to estimate and such classified (secret) information could not be obtained but should be included if possible. Additionally, the costs for work-related sick leave and rehabilitation should be included for a complete calculation. However, these costs were not calculated since this was not included in the objective of the study. Thus, based on all data obtained, a principle calculation will look like this:

$\mathrm{C}=\mathrm{W}\left(\mathrm{N}_{\text {on }} \times \mathrm{Ta}_{\text {on }}+\mathrm{N}_{\text {off }} \times \mathrm{Ta}_{\text {off }}+\mathrm{N}_{\mathrm{au}} \times \mathrm{Ta}_{\text {off }}+\mathrm{N}_{\text {yard }} \times \mathrm{T}_{\text {ty }}\right)+\mathrm{N}_{\text {scrap }} \times \mathrm{C}_{\text {scrap }}+\mathrm{C}_{\mathrm{fb}}+$ $\mathrm{WRSL}+\mathrm{C}_{\text {fcomp }}+\mathrm{C}_{\mathrm{rec}}+\mathrm{C}_{\mathrm{bw}}$

Number of errors:

$\mathrm{N}_{\text {on }}=$ number of quality errors online

$\mathrm{N}_{\text {off }}=$ number of quality errors offline

$\mathrm{N}_{\mathrm{au}}=$ number of audit quality remarks

$\mathrm{N}_{\text {scrap }}=$ number of scrapped items

$\mathrm{N}_{\text {yard }}=$ number of cars with errors in the yard

$\mathrm{N}_{\mathrm{fb}}=$ number of factory blocked cars

Action time (minutes):

$\mathrm{Ta}_{\mathrm{on}}=$ action time online

$\mathrm{Ta}_{\text {off }}=$ action time offline

$\mathrm{T}_{\mathrm{ty}}=$ Transfer time of cars in the yard 
Costs:

$\mathrm{C}=$ total costs for all manual assembly related errors

$\mathrm{W}=$ labor cost/time unit

$\mathrm{C}_{\mathrm{s}}=$ scrap cost/item

WRSL $=$ cost for work related sick leave and rehabilitation

$\mathrm{C}_{\mathrm{fb}}=$ cost for errors of factory blocked cars (Tracy)

$\mathrm{C}_{\mathrm{fc}}=$ cost for errors of Factory complete cars (VRT/PFU)

$\mathrm{C}_{\mathrm{rec}}=$ cost for recall/repair of cars distributed to the customers (FARG)

$\mathrm{C}_{\mathrm{bw}}=$ cost for lost brand image and customer's dissatisfaction (badwill).

\section{DISCUSSION/CONCLUSIONS}

A practical and simple calculation model is often asked for by engineers but such a model cannot be simple for two reasons: Suitable calculation data is often missing in companies and there are many factors to consider for a complete calculation that prevents simplicity. However, the results in this study show that the majority of assembly errors and related costs (95-97\%) were found and solved in production. For practical reasons and in many cases these error data and associated costs might be sufficient enough as decision support in the choice of manufacturing and ergonomics solutions. Table 6 clearly demonstrates that the later errors are fixed the more costly they are. Errors found and fixed in the market were 12,2 times more costly compared to errors found and fixed in the plant. Errors fixed online were 10,3 times less costly than errors fixed offline in the plant. The most profitable is to foresee and prevent assembly errors altogether by making holistic assessments as early as possible in product development stages. The earlier a holistic approach, prediction of failure rate and action costs can be made, the more money can be saved altogether. Besides, both ergonomics and quality issues can be proactively solved at the same time.

\section{ACKNOWLEDGEMENTS}

This project is funded by Vinnova $\mathrm{AB}$ within the program "Sustainable production: Decision Support for Early Estimation of Cost of Poor Quality". The project was carried out in the Production Area of Advance at Chalmers University of Technology, Göteborg, Sweden, in collaboration with Volvo Car Corporation, Volvo Trucks and Swerea IVF. The support is gratefully acknowledged.

\section{REFERENCES}

Beevis, D., Slade, I.M. (2003). Ergonomics-costs and benefits. Applied Ergonomics, 34 (5), pp. 413-418 (part 1).Booker, J.D., Raines, M./Swift, K.G. (2001). Designing Capable and Reliable Products. Butterworth-Heinemann, Oxford, ISBN: 9780750650762.

Broberg, O. (1997). Integrating ergonomics into the product development process. International Journal of Industrial Ergonomics 19: 317-327. 
Dul, J., Neumann, P. (2009). Ergonomics Contributions to Company Strategies. Applied Ergonomics 40 (2009)745-752.

Eklund, J. (1995).Relationships between ergonomics and quality in assembly work. Applied Ergonomics Vol. 26, No. 1, pp 15-20, 1995.

Eklund, J. (1997). Ergonomics, quality and continuous improvement - conceptual and empirical relationships in an industrial context. Ergonomics, 1997, Vol. 40, No. 10, 982-1001

Eklund, J. (1999). Ergonomics and quality management - humans in interaction with technology, work environment and organization. International Journal of Occupational Safety and Ergonomics. 5(2), 143-160.

Falck, A., (2007). Virtual and Physical Methods for Efficient Ergonomics Risk Assessments - A Development Process for Application in Car Manufacturing. Thesis for the Degree of Licentiate of Philosophy. Department of Product and Production Development, Chalmers University of Technology, Göteborg, Sweden. Report no. 21. ISSN 1652-9243.

Falck, A., Örtengren, R., Högberg, D: (2010). The Impact of Poor Assembly Ergonomics on Product Quality: A Cost-Benefit Analysis in Car Manufacturing. Human Factors and Ergonomics in Manufacturing and Service Industries 20 (1) 24-41 (2010).

Googins, R.W., Spielholz, P., Nothstein, G.L. (2008). Estimating the effectiveness of ergonomics interventions through case studies: Implications for predictive cost- benefit analysis. Journal of Safety Research 39(2008) 339-344.

Haslegrave, C.M., Holmes, K.(1994). Integrating ergonomics and engineering in the technical design process. Applied ergonomics 1994 25(4) 211-220.

Hendrick, H.W. (2003). Determining the cost-benefits of ergonomics projects and factors that lead to their success. Applied Ergonomics, Vol. 34, pp. 419-427.

Hendrick, H.W. (2008). Applying ergonomics to systems: Some documented "lessons learned". Applied Ergonomics 39 (2008) 418-426.

Maudgalya,T., Genaidy, A. Shell, R. (2008). Productivity-quality-cost-safety: A sustained approach to competitive advantage - a systematic review of the National Safety Council's case studies in safety and productivity. Human Factors and Ergonomics in Manufacturing, 18(2), 152-179.

Langaa Jensen, P. (2002). Human factors and ergonomics in the planning of production. International Journal of Industrial Ergonomics, 29 (2002) 121-131.

Morse, M., Kros, J., Scott Nadler, S. (2009). A decision model for the analysis of ergonomic investments. International Journal of Production Research, Vol. 47 (21), pp. 6109-6128.

Skepper, N., Straker, L., Pollock, C. (2000). A case study of the use of ergonomics information in a heavy engineering design process. International Journal of Industrial Ergonomics 26 (2000) 425-435.

Sunwook, K., Seol, H., Ikuma, L.H., Nussbaum, M.A. (2008). Knowledge and opinions of designers of industrialized wall panels regarding incorporating ergonomics in design. International Journal of Industrial Ergonomics 38 (2008) 150-157.

Wulff, A., Westgaard, R., Rasmussen, B. (2000). Documentation in large-scale engineering design: information processing and defensive mechanisms to generate information overload. International Journal of Industrial Ergonomics, Vol. 25, pp. 295-310.

Yeow, P., \& Nath Sen, R. (2006). Productivity and quality improvements, revenue increment, and rejection cost reduction in the manual component insertion lines through the application of ergonomics. International Journal of Industrial Ergonomics, 36 (2006) 367-377. 